\title{
Publisher Correction: Low replicability can support robust and efficient science
}

\section{Stephan Lewandowsky (D) \& Klaus Oberauer (i)}

Correction to: Nature Communications https://doi.org/10.1038/s41467-019-14203-0, published online 17 January 2020.

The original HTML version of this Article was updated after publication because the previous HTML version linked to an incorrect Source data file. As Source data were not provided in this file, this link has been removed. The original Data availability statement is correct and includes a link where data and analysis code can be accessed.

Published online: 11 August 2020

\begin{abstract}
(c) (i) Open Access This article is licensed under a Creative Commons Attribution 4.0 International License, which permits use, sharing, adaptation, distribution and reproduction in any medium or format, as long as you give appropriate credit to the original author(s) and the source, provide a link to the Creative Commons license, and indicate if changes were made. The images or other third party material in this article are included in the article's Creative Commons license, unless indicated otherwise in a credit line to the material. If material is not included in the article's Creative Commons license and your intended use is not permitted by statutory regulation or exceeds the permitted use, you will need to obtain permission directly from the copyright holder. To view a copy of this license, visit http://creativecommons.org/licenses/by/4.0/.
\end{abstract}

(C) The Author(s) 2020 